
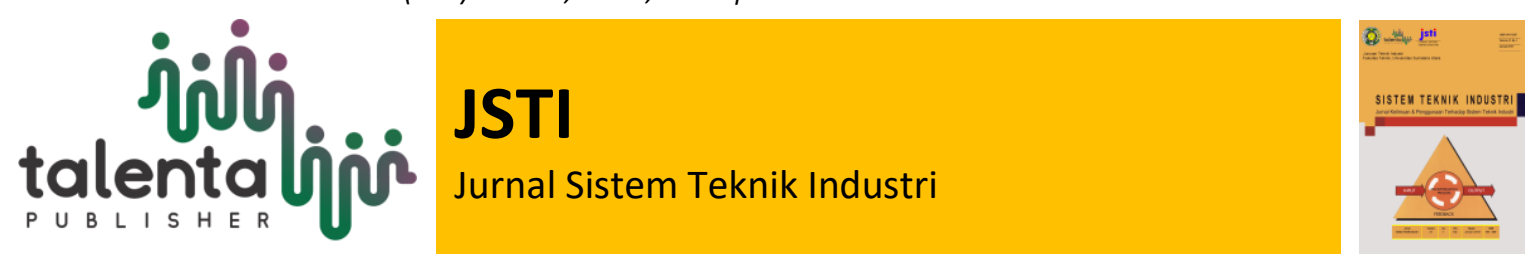

\title{
Analisis Risiko Keterlambatan Material dan Komponen pada Proyek Pembangunan Kapal dengan Metode House of Risk (HOR) Studi Kasus: Pembangunan Kapal Ro-Ro 300 GT Danau Toba
}

\author{
Maria Elfrida Sibueal dan Hadi Sutanto Saragi1 \\ ${ }^{1}$ Program Studi Manajemen Rekayasa, Fakultas Teknologi Industri, Institut Teknologi Del
}

\begin{abstract}
Abstrak. Proses pelaksanaan proyek yang sesuai dengan kontrak merupakan hal yang sangat penting dalam pembangunan kapal Ro-Ro 300 GT Danau Toba, milik Kementerian Perhubungan Republik Indonesia. Proses pelaksanaan proyek pembangunan kapal Ro-Ro 300 GT Danau Toba tidak terhindar dari risiko baik skala kecil maupun besar yang menimbulkan kerugian berupa tambahan waktu, pembengkakan biaya dari rencana awal, bahkan mempengaruhi kualitas baik buruknya konstruksi kapal. Salah satu risiko yang mempengaruhi ketepatan waktu penyelesaian proyek pembangunan kapal Ro-Ro 300 GT Danau Toba adalah keterlambatan material dan komponen. Tujuan penelitian ini, menentukan material dan komponen yang memiliki risiko ekstrim, mengidentifikasi risiko keterlambatan material dan komponen dan memberikan rekomendasi berupa tindakan pencegahan terhadap keterlambatan material dan komponen pada pelaksanaan pembangunan kapal Ro-Ro 300 GT Danau Toba. Metode yang digunakan adalah House of Risk (HOR), dengan hasil yang diharapkan dapat menentukan prioritas tindakan pencegahan yang diusulkan. Hasil penelitian menunjukkan bahwa material dan komponen dengan risiko ekstrim adalah pelat geladak utama tepi $8 \mathrm{~mm}$, pelat geladak utama tipikal $12 \mathrm{~mm}$ dan gading utama (main frame). Dari hasil HOR I, pelat geladak utama tepi $8 \mathrm{~mm}$ dan pelat geladak utama tipikal $12 \mathrm{~mm}$ didapatkan dari 22 penyebab risiko terdapat 14 penyebab risiko, sedangkan gading utama (main frame) didapatkan dari 17 penyebab risiko terdapat 11 penyebab risiko yang perlu diberikan penanganan. Hasil HOR II, menunjukkan pelat geladak utama tepi $8 \mathrm{~mm}$ dan pelat geladak utama tipikal $12 \mathrm{~mm}$ dari 20 tindakan pencegahan terdapat 11 tindakan pencegahan dan gading utama (main frame) dari 14 tindakan pencegahan terdapat 8 tindakan pencegahan yang perlu dilakukan terlebih dahulu.
\end{abstract}

Kata Kunci: Pembangunan Kapal; Keterlambatan; Material dan Komponen; Risiko; House of Risk (HOR)

${ }^{*}$ Corresponding author at: Laguboti 22381, Sumatera Utara, Indonesia 


\begin{abstract}
The process of implementing project in accordance with contract is very important in the ship building Ro-Ro 300 GT Lake Toba construction project, owned by Ministry Transportation of Republic Indonesia. In the implement of the ship building Ro-Ro $300 \mathrm{GT}$ Lake Toba construction project is unavoidable from the risk of small and large scale which cause losses in additional time, over budget, and poor quality of the ship construction. One of the risk which affect the timeliness of completion the ship building Ro-Ro 300 GT Lake Toba construction project is the delay of materials and components. The purpose in this research is determine the materials and components with extreme risks, identify the risk of material and component delays and provide recommendations in the form of preventive actions against delays in material and components in the ship building Ro-Ro 300 GT Lake Toba construction project. The method used is the House of Risk (HOR), with the expected results can determine the priority of the proposed preventive actions. The results showed that the material and components with extreme risk were the $8 \mathrm{~mm}$ of edge main deck plate, the $12 \mathrm{~mm}$ of typical main deck plate and main frame. From the results of HOR I, the $8 \mathrm{~mm}$ of edge main deck plate, the $12 \mathrm{~mm}$ of typical main deck from 22 risk agents, only 14 risk agents, and the main frame from 17 risk agents, only 11 risk agents that need to be given handling. The result of HOR II, the $8 \mathrm{~mm}$ of edge main deck plate, the $12 \mathrm{~mm}$ of typical main deck from 20 preventive actions, only 11 preventive actions and the main frame from 14 preventive actions, only 8 preventive actions are selected to priorities preventive actions
\end{abstract}

Keywords: Ship Building; Delay; Material and Component; Risk; House of Risk (HOR)

Received 12 July 2019 | Revised 26 July 2019 | Accepted 26 July 2019

\title{
1. Introduction
}

Pelaksanaan proyek pembangunan kapal Ro-Ro 300 GT Danau Toba di Pantai Pasir Putih, Desa Parparean II, Kecamatan Porsea, Toba Samosir merupakan salah satu proyek Kementerian Perhubungan Republik Indonesia untuk dikelola di kawasan Danau Toba, Sumatera Utara. Proyek pembangunan kapal Ro-Ro 300 GT Danau Toba memberikan keuntungan untuk melayani penyeberangan di Danau Toba dan menunjang sektor pariwisata di kawasan Danau Toba. Proyek ini dimulai pada tanggal 1 Oktober 2018 dan direncanakan launching pada tanggal 30 November 2019. Jangka waktu penyelesaian proyek ini adalah 15 bulan.

Proses pelaksanaan proyek pembangunan kapal Ro-Ro 300 GT Danau Toba tidak terhindar dari risiko baik skala kecil dan skala besar yang menimbulkan beberapa kerugian berupa tambahan waktu, pembengkakan biaya dari rencana awal, bahkan mempengaruhi kualitas baik buruknya konstruksi kapal. [1] [2]. Untuk dapat menyelesaikan proyek sesuai dengan yang telah disepakati dalam kontrak maka perlu mengidentifikasi dan mengurangi kemungkinan risiko. Risiko diilustrasikan sebagai kombinasi dari konsekuensi atas suatu kejadian (termasuk perubahan suatu kondisi) dan kemungkinan yang berhubungan dengan suatu kejadian. [3].

Table 1 Risiko Keterlambatan Material dan Komponen

\begin{tabular}{|c|c|c|c|c|}
\hline No & Material dan Komponen & Tingkat Kem & Level Dampak & Level Risiko \\
\hline 1 & Pelat Alas & Sangat kecil & Sedang & Rendah \\
\hline 2 & $\begin{array}{l}\text { Pelat Bilga } \\
\text { Pelat Sisi Rumah Geladak }\end{array}$ & Sangat kecil & Sedang & Medium \\
\hline 3 & Utama & Sangat kecil & Tinggi & Tinggi \\
\hline 4 & Gading Utama (Main Frame) & Sangat besar & Tinggi & Ekstrim \\
\hline
\end{tabular}

Pada Tabel 1 dapat dilihat bahwa risiko yang mempengaruhi ketepatan waktu penyelesaian proyek pembangunan kapal Ro-Ro 300 GT Danau Toba adalah keterlambatan material dan komponen dengan tingkat kemungkinan (frekuensi keterlambatan) dan level dampak 
(kepentingan, dilihat harganya). [4]. Keterlambatan ini sangat merugikan pihak-pihak terkait, baik kontraktor maupun pemilik proyek itu sendiri. [5].

Berdasarkan wawancara yang telah dilakukan dengan project manager di galangan kapal pembangunan kapal Ro-Ro 300 GT Danau Toba bahwa masalah/kendala yang ditimbulkan keterlambatan material dan komponen baik kepada pemilik proyek maupun pihak-pihak yang terlibat pada proyek, misalnya pembengkakan biaya, jadwal yang berantakan, menumpuknya tagihan, dan menganggurnya pekerja di lapangan karena tidak ada pekerjaan yang dilakukan. Kendala/masalah lainnya dapat disebabkan oleh kegagalan dalam mengelola proses pengadaan yang dapat berakibat buruk dalam kegiatan pelaksanaan proyek pembangunan kapal seperti keterlambatan proyek, penggunaan bahan baku yang buruk, dan lain-lain. Sebagai sebuah proyek, pelaksanaan proyek pembangunan kapal Ro-Ro 300 GT Danau Toba memiliki batasan yang harus diperhatikan, yaitu waktu, biaya, dan kualitas. [6].

Oleh karena itu, penelitian ini dilakukan untuk penentuan material dan komponen berisiko ekstrim, identifikasi risiko, analisa risiko, evaluasi risiko, dan penanganan risiko dengan menggunakan model House of Risk (HOR). Metode House of Risk (HOR) memperkenalkan pendekatan penanganan risiko, yaitu suatu metode yang terfokus merumuskan tindakan pencegahan dan penanganan penyebab risiko yang berpotensi menimbulkan lebih dari satu risiko. [7] [8].

Dengan adanya penelitian mengenai manajemen risiko, diharapkan suatu proses penanganan yang tepat untuk mengurangi risiko keterlambatan material dan komponen yang dapat membantu pihak yang terlibat pada proyek pembangunan kapal untuk mengambil keputusan dan mengatasi penyebab risiko sehingga biaya, jadwal dan kualitas sesuai dengan yang telah ditetapkan oleh pihak-pihak terkait di dalam proyek.

\section{Metodologi Penelitian}

Dalam penelitian ini dilakukan analisis risiko keterlambatan material dan komponen dengan menggunakan metode Risk Mapping dan House of Risk (HOR). Pemetaan material dan komponen dengan kategori risiko ekstrim (risk extreme) digunakan metode Risk Mapping. Selanjutnya, untuk mengurangi risiko keterlambatan material dan komponen digunakan metode House of Risk (HOR) dengan memprioritaskan penyebab risiko yang terlebih dahulu dilakukan tindakan pencegahan. Penilaian dalam pemetaan risiko yaitu level dampak dan tingkat kemungkinan risiko yang diperlihatkan pada Tabel 2. [9] [10]. 
Table 2 Skala Risk Mapping

\begin{tabular}{lllllll}
\hline \multirow{2}{*}{$\begin{array}{c}\text { Tingkat } \\
\text { Kemungkinan }\end{array}$} & \multicolumn{1}{c}{1} & \multicolumn{4}{c}{ Level Dampak } \\
\cline { 2 - 7 } & $\begin{array}{c}\text { Tidak } \\
\text { signifikan }\end{array}$ & Minor & Medium & Mayor & Malapetaka \\
\hline E Sangat besar & H & H & E & E & E \\
D Besar & M & H & H & E & E \\
C Sedang & L & M & H & E & E \\
B Kecil & L & L & M & H & E \\
A Sangat kecil & L & L & M & H & H \\
\hline
\end{tabular}

Dengan menggunakan metode House of Risk (HOR) yang didasarkan pada kebutuhan akan manajemen risiko yang berfokus pada tindakan pencegahan untuk menentukan penyebab risiko mana yang menjadi prioritas yang kemudian akan diberikan tindakan pencegahan atau penanggulangan risiko. [7] [8]. Dalam penelitian ini mengusulkan dua model penyebaran yan disebut HOR yang keduanya didasarkan pada HOQ yang dimodifikasi:

a. HOR 1 digunakan untuk menentukan sumber risiko mana yan diprioritaskan untuk dilakukan tindakan pencegahan. Adapun langkah dalam membuat matriks House of Risk (HOR) I adalah:

(1.) Identifikasi pembagian proses bisnis/aktivitas perusahaan yang bertujuan untuk mengetahui dimana risiko tersebut dapat muncul

(2.) Identifikasi risk event $\left(\mathrm{E}_{\mathrm{i}}\right)$ dan pengukuran level dampak $\left(\mathrm{S}_{\mathrm{i}}\right)$

(3.) Identifikasi risk agent $\left(\mathrm{A}_{\mathrm{i}}\right)$ dan pengukuran tingkat kemungkinan $\left(\mathrm{O}_{\mathrm{j}}\right)$

(4.) Penyusunan matriks untuk menghubungkan masing-masing risk agent dengan risk event dengan nilai korelasi $\left(\mathrm{R}_{\mathrm{ij}}\right)$ terdiri dari $(0,1,3,9)$ dimana 0 menunjukkan tidak ada hubungan korelasi, 1 menunjukkan korelasi rendah, 3 menunjukkan korelasi sedang, dan 9 menunjukkan korelasi tinggi.

(5.) Perhitungan nilai ARP dari $A_{j}$ dengan menggunakan persamaan: $A R P_{j}=O_{j} \Sigma S_{i} R_{j}$

\begin{tabular}{|c|c|c|c|c|c|c|c|c|c|}
\hline \multirow[b]{2}{*}{$\begin{array}{l}\text { Business } \\
\text { Processes }\end{array}$} & \multirow[b]{2}{*}{$\begin{array}{c}\text { Risk Event } \\
\text { (Ei) }\end{array}$} & \multicolumn{7}{|c|}{ Risk Agents ( $A \bar{j})$} & \multirow[b]{2}{*}{$\begin{array}{c}\text { Severity of } \\
\text { Risk Event } i \\
\text { (Si) }\end{array}$} \\
\hline & & $\mathrm{Al}$ & A2 & A3 & A4 & A5 & A6 & A 7 & \\
\hline \multirow[t]{2}{*}{ Plan } & E1 & R.11 & $\mathrm{R} .2$ & $\mathrm{R} 13$ & $\ldots$ & $\ldots$ & $\ldots$ & $\ldots$ & S1 \\
\hline & E2 & $\mathrm{R} 21$ & $\mathrm{R} .22$ & $\ldots$ & $\ldots$ & $\ldots$ & .. & .. & S2 \\
\hline \multirow[t]{2}{*}{ Source } & E3 & $\mathrm{R} 31$ & $\ldots$ & $\ldots$ & $\ldots$ & $\ldots$ & $\ldots$ & $\ldots$ & S3 \\
\hline & E4 & R41 & $\ldots$ & $\ldots$ & $\ldots$ & $\ldots$ & $\ldots$ & $\ldots$ & S4 \\
\hline \multirow[t]{2}{*}{ Make } & E5 & $\ddot{*}$ & $\ldots$ & $\ldots$ & $\ldots$ & $\ldots$ & $\ldots$ & $\ldots$ & S5 \\
\hline & E6 & $\ldots$ & $\ldots$ & $\ldots$ & $\ldots$ & $\ldots$ & $\ldots$ & $\ldots$ & S6 \\
\hline \multirow[t]{2}{*}{ Deliver } & E7 & $\ldots$ & $\ldots$ & $\ldots$ & $\ldots$ & $\ldots$ & $\ldots$ & $\ldots$ & S7 \\
\hline & E8 & $\ldots$ & $\ldots$ & $\ldots$ & $\ldots$ & $\ldots$ & $\ldots$ & $\ldots$ & S8 \\
\hline Return & E9 & $\ldots$ & $\ldots$ & $\ldots$ & $\ldots$ & $\ldots$ & $\ldots$ & Rij & S9 \\
\hline \multicolumn{2}{|c|}{ Occurrence of Agent $j$} & $\mathrm{Ol}$ & $\mathrm{O} 2$ & $\mathrm{O} 3$ & 04 & 05 & 06 & 07 & \\
\hline \multicolumn{2}{|c|}{$\begin{array}{l}\text { Aggregate Risk } \\
\text { Potential } j\end{array}$} & ARP1 & ARP2 & ARP3 & ARP4 & ARP5 & ARP6 & ARP7 & \\
\hline \multicolumn{2}{|c|}{$\begin{array}{l}\text { Priority Rank of } \\
\text { Agent } j\end{array}$} & & & & & & & & \\
\hline
\end{tabular}

Figure 1 Matriks HOR I

b. HOR 2 adalah untuk memberikan prioritas tindakan dengan mempertimbangkan sumber daya biaya yang efektif. Adapun langkah dalam membuat matriks House of Risk II adalah: 
1. Pilih risk agent dengan tingkat prioritas yang tinggi (menggunakan Diagram Pareto) berdasarkan output dari HOR fase 1.

2. Identifikasi tindakan pencegahan yang relevan untuk mencegah timbulnya risiko.

3. Menentukan hubungan antara masing-masing tindakan pencegahan pada masingmasing pemicu risiko (risk agent) dengan menggunakan nilai 0, 1, 3 dan 9. Dimana angka 0 tersebut menunjukkan hubungan yang bersifat tidak ada korelasi (no correlation) dan nilai 1, 3, 9 menunjukkan korelasi rendah, sedang dan kuat antara tindakan $\mathrm{k}$ dengan agent $\mathrm{j}$. Menghitung tingkat efektivitas dari masing-masing tindakan sebagai berikut: $\mathrm{TE}_{\mathrm{k}}=\Sigma_{\mathrm{i}} \mathrm{ARP}_{\mathrm{j}} \mathrm{E}_{\mathrm{jk}}$

4. Mengukur tingkat kesulitan dengan merepresentasikan masing-masing tindakan pencegahan.

5. Menghitung total efektivitas untuk menentukan besaran rasio dengan rumus sebagai berikut: $\mathrm{ETD}_{\mathrm{k}}=\mathrm{TE}_{\mathrm{k}} / \mathrm{D}_{\mathrm{k}}$

6. Melakukan skala prioritas mulai dari nilai ETD tertinggi hingga yang terendah dan diagram pareto untuk tindakan pencegahan yang terlebih dahulu dilakukan.

\begin{tabular}{|c|c|c|c|c|c|c|}
\hline \multirow{2}{*}{ 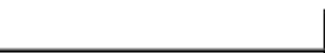 } & \multirow{2}{*}{\multicolumn{5}{|c|}{ Preventive Action (PAk) }} & \multirow{3}{*}{$\begin{array}{c}\text { Aggregate } \\
\text { Risk } \\
\text { Potentials } \\
\text { (ARPj) }\end{array}$} \\
\hline & & & & & & \\
\hline To be treated risk agent $(A j)$ & PAl & PA2 & $\mathrm{PA} 3$ & PA4 & PA5 & \\
\hline Al & E11 & E12 & E13 & $\ldots$ & $\ldots$ & ARPl \\
\hline $\mathrm{A} 2$ & E21 & E22 & $\ldots$ & $\ldots$ & $\ldots$ & ARP2 \\
\hline A.3 & E31 & $\ldots$ & $\ldots$ & $\ldots$ & $\ldots$ & ARP3 \\
\hline $\mathrm{A} 4$ & $\ldots$ & $\ldots$ & $\ldots$ & $\ldots$ & $\ldots$ & ARP4 \\
\hline A.5 & $\ldots$ & $\ldots$ & $\ldots$ & $\ldots$ & Ejk & ARP5 \\
\hline Total efectiveness of action $k$ & TEl & TE2 & TE3 & TE4 & TE5 & \\
\hline $\begin{array}{l}\text { Degree of difficulty } \\
\text { performing action } k\end{array}$ & D1 & D2 & D3 & D4 & D5 & \\
\hline Effectiveness to difficulty ratio & ETD1 & ETD2 & ETD3 & ETD4 & ETD5 & \\
\hline Rank of priority & $\mathrm{R} 1$ & $\mathrm{R} 2$ & $\mathrm{R} 3$ & R4 & R5 & \\
\hline
\end{tabular}

Figure 2 Matriks HOR II

Pengumpulan data dalam penelitian ini dilakukan dengan beberapa cara, antara lain teknuk brainstorming, observasi lapangan, wawancara, hasil kuesioner, dan dokumen proyek pembangunan kapal Ro-Ro 300 GT Danau Toba.

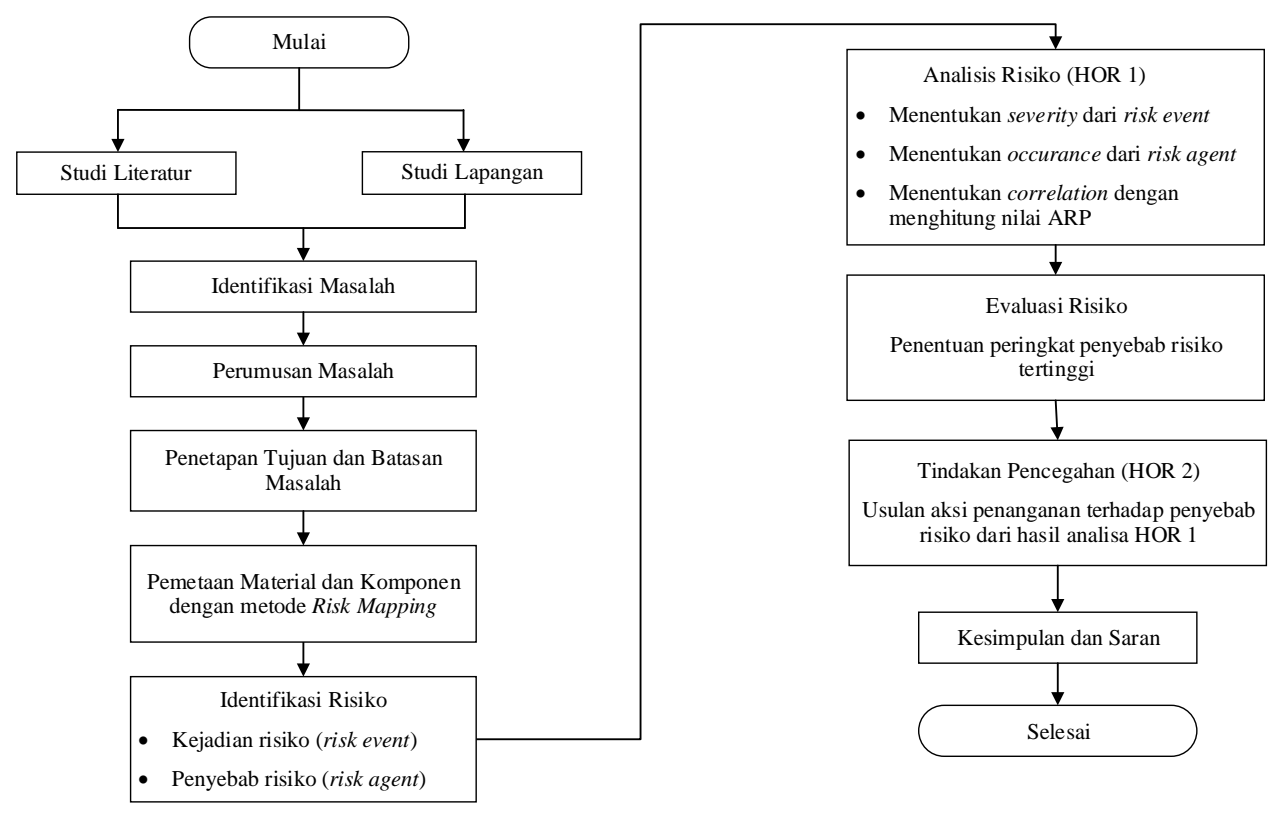

Figure 3 Diagram Alir Penelitian 
Kerangka kerja penelitian merupakan suatu gambaran sistematis yang akan dijadikan sebagai acuan dalam melakukan penelitian dimulai dari identifikasi masalah di galangan kapal. Langkah berikutnya pemetaan material dan komponen yang memiliki risiko ekstrim, identifikasi risiko, analisis risiko (HOR 1) untuk menentukan sumber risiko mana yang diprioritaskan untuk dilakukan tindakan pencegahan, dan tindakan pencegahan (HOR2) untuk menentukan penanganan yang tepat untuk mengurangi dan mengatasi risiko.

\section{Analisis Data dan Pembahasan}

\subsection{Pemetaan Risiko Material dan Komponen}

Pemetaan risiko keterlambatan material dan komponen pada pelaksanaan pembangunan kapal untuk menentukan bahan baku pembuatan kapal berupa material dan komponen yang memiliki risiko ekstrim (extreme risk). Pemetaan dilakukan dengan menggunakan metode Risk Mapping. Penentuan material dan komponen berisiko dengan tingkat kemungkinan (frekuensi keterlambatan) dan level dampak (kepentingan, dilihat dari harganya) akan diperlihatkan pada Tabel 3.

Table 3 Peta Risiko (Risk Mapping) Risiko Material dan Komponen

\begin{tabular}{|c|c|c|c|c|c|}
\hline \multirow{3}{*}{$\begin{array}{c}\text { Tingkat } \\
\text { Kemungkinan }\end{array}$} & \multicolumn{5}{|c|}{ Level Dampak } \\
\hline & 1 & 2 & 3 & 4 & 5 \\
\hline & $\begin{array}{c}\text { Tidak } \\
\text { signifikan }\end{array}$ & Minor & Medium & Mayor & Malapetaka \\
\hline $\begin{array}{l}\text { E Sangat besar } \\
\text { D Besar }\end{array}$ & & & 31 & & \\
\hline C Sedang & & & & 13 & 12 \\
\hline B Kecil & & & & & \\
\hline A Sangat kecil & $3,27,49$ & $\begin{array}{l}10, \quad 15, \\
21,43,53\end{array}$ & $\begin{array}{l}4,5,6,11, \\
17,22,50, \\
51\end{array}$ & $\begin{array}{l}1,7,8, \\
14, \quad 18, \\
26, \quad 35, \\
55, \quad 56, \\
58,61\end{array}$ & $\begin{array}{l}2,9,16,19,20,23,24, \\
25,28,29,30,32,33, \\
34,36,37,38,39,40, \\
41,42,44,45,46,47, \\
48,52,54,57,59,60, \\
62,63,64\end{array}$ \\
\hline
\end{tabular}

Berdasarkan peta risiko (risk mapping), dimana risiko akan terbagi menjadi empat golongan, yaitu low risk, moderate risk, high risk, dan extreme risk. Pada peta risiko menunjukkan pada posisi low risk berjumlah 8 , moderate risk berjumlah 8 , high risk berjumlah 45 , dan extreme risk berjumlah 3. Material dan komponen berisiko ekstrim (risk extreme), yaitu pelat geladak utama tepi $8 \mathrm{~mm}$, pelat geladak utama tipikal $12 \mathrm{~mm}$ dan gading utama (main frame) sehingga perlu dilakukan pengamatan rinci dan penanganan harus level pemimpin.

\subsection{Identifikasi Risiko}

Setelah material dan komponen yang berisiko ekstrim (risk extreme) telah ditentukan maka akan dilakukan identifikasi risiko. Pada tahap identifikasi risiko dilakukan menggunakan metode House of Risk (HOR) bahwa risiko yang diidentifikasi adalah kejadian risiko (risk event) dan penyebab risiko (risk agent). Selanjutya, hasil identifikasi risiko dijadikan sebagai kuesioner dan 
hasil penilaian level dampak (severity) dan tingkat kemungkinan (occurance) adalah rata-rata pembobotan yang dilakukan 20 responden terhadap kejadian risiko dan penyebab risiko yang teridentifikasi. Adapun yang menjadi variabel-variabel risiko dikategorikan berdasarkan risiko proses perencanaan, pengadaan, quality control dan finansial.

Identifikasi risiko akan menghasilkan suatu daftar risiko yang berpotensi terjadi pada material dan komponen seperti pelat geladak utama tepi $8 \mathrm{~mm}$, pelat geladak utama tipikal $12 \mathrm{~mm}$, dan gading utama (main frame) yang dapat dilihat pada Tabel 4 dan Tabel 5. Risiko yang teridentifikasi selanjutnya atau risiko yang berpotensi terjadi disebut sebagai kejadian risiko (risk event), kemudian akan ditentukan level keparahan dampak (severity) dengan nilai mulai dari 1 hingga 10. Nilai $S_{i}$ (severity) 1 menyatakan bahwa tidak ada dampak risiko yang terjadi, sedangkan nilai 10 menunjukkan dampak risiko yang sangat berbahaya. Berikut ini adalah risiko yang teridentifikasi pada pelaksanaan proyek pembangunan kapal Ro-Ro 300 GT Danau Toba:

a. Identifikasi kejadian risiko (risk event)

(1.) Pelat Geladak Utama Tepi $8 \mathrm{~mm}$ dan Pelat Geladak Utama Tipikal $12 \mathrm{~mm}$

Table 4 Hasil Identifikasi Kejadian Risiko (Risk Event) Pelat Geladak Utama Tepi 8 mm dan Pelat Geladak Utama Tipikal $12 \mathrm{~mm}$

\begin{tabular}{ccc}
\hline Kode & Kejadian Risiko (Risk Event) & Severity \\
Risiko & Perencanaan \\
E1 & Kesalahan permintaan pembelian & 8,4 \\
E2 & Kegagalan pengendalian terhadap jadwal permintaan & 7,5 \\
E3 & pembelian & 8,1 \\
E4 & Kegagalan komunikasi dan koordinasi antar pihak yang terlibat & 6,3 \\
E5 & di dalam proyek & 6,2 \\
E6 & Terjadinya kenaikan harga material dan komponen & 7,4 \\
E7 & Kerusakan / kehilangan material dan komponen & \\
E8 & Pengadaan & 7,6 \\
E9 & Kesalahan pengadaan material dan komponen & 6,8 \\
E10 & Ketidaksesuaian jumlah material dan komponen & 8,0 \\
E11 & Kesulitan akses lokasi proyek & Quality Control \\
E12 & Ketidaksesuaian material dan komponen terhadap spesifikasi & 5,7 \\
E13 & dan standar yang berlaku & 7,6 \\
& Pengembalian material dan komponen karena tidak dapat & 7,2 \\
E14 & digunakan lagi & 6,2 \\
E15 & Finansial & \\
E16 & Kegurangan dana untuk kebutuhan material dan komponen & 7,7 \\
E17 & Kepercayaan supplier terhadap kemampuan & 7,2 \\
\hline
\end{tabular}

Hasil identifikasi kejadian risiko (risk event) pelat geladak utama tepi $8 \mathrm{~mm}$ dan pelat geladak utama tipikal $12 \mathrm{~mm}$ yang mungkin terjadi pada pelaksanaan pembangunan kapal Ro-Ro $300 \mathrm{GT}$ memperoleh sebanyak 17 kejadian risiko. Hasil identifikasi kejadian risiko $\left(E_{i}\right)$ berjumlah 6 pada 
perencanaan, 4 pada pengadaan, 3 pada quality control, dan 4 pada finansial. Kejadian risiko (risk event) dengan tingkat keparahan paling tinggi adalah pada proses perencanaan, kesalahan permintaan pembelian yaitu 8,4 .

(2.) Gading Utama (Main Frame)

Table 5 Hasil Identifikasi Kejadian Risiko (Risk Event) Gading Utama (Main Frame)

\begin{tabular}{|c|c|c|}
\hline Kode Risiko & Kejadian Risiko (Risk Event) & Severity \\
\hline & Perencanaan & \\
\hline E1 & Keterlambatan gambar desain & 8,4 \\
\hline E2 & Kebijakan pemerintah yang berubah & 8,2 \\
\hline E3 & Persiapan dan persetujuan desain terlambat & 8,2 \\
\hline E4 & Permasalahan dalam proses perijinan & 6,6 \\
\hline E5 & Kesalahan gambar desain & 8,1 \\
\hline E6 & Keterlambatan administrasi & 6,2 \\
\hline \multicolumn{3}{|c|}{ Pengadaan } \\
\hline E7 & Keterlambatan dalam proses pembuatan dokumen kontrak & 7,7 \\
\hline E8 & Perbedaan material dan komponen yang diterima & 7,2 \\
\hline E9 & $\begin{array}{c}\text { Kegagalan koordinasi kerja antar pihak yang terlibat di dalam } \\
\text { proyek }\end{array}$ & 6,5 \\
\hline \multicolumn{3}{|c|}{ Quality Control } \\
\hline E10 & Kehilangan data historis material dan komponen & 5,7 \\
\hline E11 & $\begin{array}{c}\text { Pemasangan material dan komponen yang tidak sesuai pada } \\
\text { kapal }\end{array}$ & 7,2 \\
\hline E12 & $\begin{array}{c}\text { Kualitas material dan komponen tidak sesuai dengan standar } \\
\text { yang sudah ditetapkan }\end{array}$ & 7,1 \\
\hline \multicolumn{3}{|c|}{ Finansial } \\
\hline E13 & Kekurangan budget & 8,5 \\
\hline E14 & Kegagalan arus kas proyek & 8,3 \\
\hline E15 & Estimasi biaya tidak sesuai (kurang) & 7,9 \\
\hline
\end{tabular}

Hasil kejadian risiko pada gading utama (main frame) memperoleh sebanyak 15 kejadian risiko yang mungkin terjadi pada pelaksanaan proyek pembangunan kapal Ro-Ro 300 GT. Risiko yang teridentifikasi mencakup kejadian pada proses perencanaan berjumlah 6 , pengadaan berjumlah 3 , quality control berjumlah 3, dan finansial berjumlah 3. Berdasarkan hasil pembobotan yang dilakukan terhadap 15 kejadian risiko yang teridentifiksi, tingkat keparahan paling tinggi adalah kekurangan budget yaitu sebesar 8,5.

\section{b. Identifikasi Penyebab Risiko (Risk Agent)}

Langkah berikutnya yaitu melakukan identifikasi penyebab risiko (risk agent). Penyebab risiko (risk agent) merupakan faktor penyebab timbulnya kejadian risiko sehingga perlu dilakukan tindakan pencegahan. Selanjutnya tingkat kemungkinan (occurance) dari penyebab risiko dengan menggunakan nilai 1 hingga 10 . Nilai $\mathrm{O}_{\mathrm{j}}$ (occurance) 1 menyatakan bahwa peluang kejadian yang jarang sekali terjadi, sedangkan nilai 10 menunjukkan peluang kejadian yang sangat sering terjadi. Pada Tabel 6 dan Tabel 7 disajikan beberapa penyebab risiko (risk agent) yang teridentifikasi pada pelaksanaan proyek pembangunan kapal Ro-Ro 300 GT Danau Toba. Penyebab risiko dapat menyebabkan lebih dari satu risk event atau sebaliknya. 
Table 6 Hasil Identifikasi Penyebab Risiko (Risk Agent) Pelat Geladak Utama Tepi 8 $\mathrm{mm}$ dan Pelat Geladak Utama Tipikal $12 \mathrm{~mm}$

\begin{tabular}{lll}
\hline Kode Risiko & \multicolumn{1}{c}{ Penyebab Risiko (Risk Agent) } & Occurance \\
\hline Perencanaan & & \\
A1 & Jenis material dan komponen tidak didefinisikan dengan & 6,1 \\
& jelas di dalam kontrak & \\
A2 & Ketidaktersediaan data material dan komponen & 6,3 \\
A3 & Rendahnya kemampuan manajerial / leadership & 6,4 \\
A4 & Penerbitan Purchase Order (PO) terlambat & 7,7 \\
A5 & Detail spesifikasi material dan komponen tidak lengkap & 7,3 \\
A6 & Spesifikasi material dan komponen tidak bisa dipenuhi & 7,9 \\
& oleh satu supplier & \\
A7 & Lamanya negosiasi pembelian & 8,4 \\
A8 & Tidak ada evaluasi kinerja dan komunikasi antar pihak & 6,1 \\
& tidak efektif & \\
A9 & Alat angkut yang tersedia tidak memadai & 5,6 \\
A10 & Kenaikan kurs mata uang yang tidak menentu & 8,4 \\
A11 & Tidak ada pengawasan di lapangan & 5,3 \\
\hline Pengadaan & & 5,6 \\
A12 & Kesalahan prosedur & 7,2 \\
A13 & Tidak ada pengawasan dari pihak supplier & 7,5 \\
A14 & Kelalaian dari pihak supplier & 6,7 \\
A15 & Kondisi lokasi dan site yang buruk & 6,3 \\
\hline Quality Control & 6,0 \\
A16 & SDM bekerja tidak efektif & 7,1 \\
A17 & Ketidaklengkapan dokumen & \\
A18 & Cacat / defect material dan komponen & 7,4 \\
\hline Finansial & & 6,8 \\
A19 & Purchase Order (PO) yang diterbitkan tidak sesuai dengan & 7,2 \\
A20 & anggaran & \\
A21 & Buruknya track record galangan dalam proses & 7,6 \\
A22 & Ketidakakuratan penjabaran budget & \\
\hline
\end{tabular}

Hasil penyebab risiko $\left(\mathrm{A}_{\mathrm{j}}\right)$ pada pelat geladak utama tepi $8 \mathrm{~mm}$ dan pelat geladak utama tipikal 12 mm yang mungkin terjadi pada pelaksanaan proyek pembangunan kapal Ro-Ro 300 GT Danau Toba memperoleh sebanyak 22 penyebab risiko dari semua proses. Penyebab risiko yang paling sering muncul adalah dengan kode A7, lamanya negosiasi pembelian dan kode A10, kenaikan kurs mata uang yang tidak menentu.

(2.) Gading Utama (Main Frame)

Table 7 Hasil Identifikasi pada Penyebab Risiko (Risk Agent) Gading Utama (Main Frame)

\begin{tabular}{lll}
\hline Kode Risiko $\quad$ Penyebab Risiko (Risk Agent) & Occurance \\
\hline \multicolumn{2}{l}{ Perencanaan } & 7,2 \\
A1 & Ketidaklengkapan drawing list & 6,1 \\
A2 & Kesalahan dan keterlambatan dalam pengambilan keputusan & 7,1 \\
A3 & $\begin{array}{l}\text { Approval Drawing dari Biro Klasifikasi Indonesia (BKI) } \\
\text { terlambat }\end{array}$ & \\
A4 & $\begin{array}{l}\text { Hubungan kerja yang tidak harmonis antar pemilik, konsultan, } \\
\text { dan kontraktor }\end{array}$ & 6,2 \\
A5 & Ketidaktersediaan designer yang berpengalaman & 5,9 \\
A6 & Proses persetujuan izin yang bertele-tele & 8,0 \\
\hline
\end{tabular}




\begin{tabular}{lll}
\hline \multicolumn{2}{l}{ Kode Risiko Penyebab Risiko (Risk Agent) } & Occurance \\
\hline \multicolumn{2}{l}{ Pengadaan } & 7,8 \\
A7 $\quad$ Perubahan desain dari pihak owner & 7,3 \\
A8 $\quad$ Spesifikasi material dan komponen tidak jelas & 6,3 \\
A9 $\quad$ Kelemahan dalam perencanaan logistic & 6,7 \\
A10 $\quad$ Evaluasi teknis yang berlarut-larut & 6,5 \\
A11 $\quad$ Terjadi perselisihan (perbedaan pendapat) antara aktor proyek & 6,9 \\
\hline Quality & Control & 5,9 \\
A12 $\quad$ Lingkungan proyek tidak aman & 6,8 \\
A13 $\quad$ SDM tidak memenuhi kompetensi & 7,0 \\
A14 $\quad$ Spesifikasi material dan komponen tidak jelas & 7,5 \\
\hline Finansial & 6,5 \\
A15 $\quad$ Ketidakakuratan penjabaran budget & \\
A16 $\quad$ Data dan informasi proyek tidak lengkap & \\
A17 $\quad$ Teknik dan metode estimasi yang tidak tepat & \\
\hline
\end{tabular}

Hasil penyebab risiko $\left(\mathrm{A}_{\mathrm{j}}\right)$ pada gading utama (main frame) memperoleh sebanyak 17 penyebab risiko dari semua proses. Hasil identifikasi penyebab risiko (risk agent) yang teridentifikasi paling sering muncul pada pelaksanaan pembangunan kapal Ro-Ro 300 GT Danau Toba adalah kode A6, proses persetujuan ijin yang bertele-tele.

\subsection{House of Risk (HOR)}

A. Analisa Risiko (HOR I)

House of Risk tahap pertama dilakukan dengan menggabungkan data kejadian risiko, penyebab risiko, korelasi antara kejadian risiko dengan penyebab risiko, ARP, dan rangking. Pada tahap HOR I akan didapatkan penyebab risiko pada proyek pembangunan kapal Ro-Ro 300 GT Danau Toba yang harus diberi prioritas terlebih dahulu. Hasil HOR I akan diperlihatkan pada Tabel 8 dan Tabel 9.

a. Pelat Geladak Utama Tepi $8 \mathrm{~mm}$ dan Pelat Geladak Utama Tipikal $12 \mathrm{~mm}$

Table 8 Matriks HOR I Pelat Geladak Utama Tepi 8 mm dan Pelat Geladak Utama Tipikal $12 \mathrm{~mm}$

\begin{tabular}{|c|c|c|c|c|c|c|c|c|c|c|c|c|c|c|c|c|c|c|c|c|c|c|c|}
\hline \multirow{2}{*}{ Risk Event } & \multicolumn{22}{|c|}{ Risk Agent } & \multirow{2}{*}{ Severity } \\
\hline & $\mathrm{A} 1$ & $\mathrm{~A} 2$ & $\mathrm{~A} 3$ & $\mathrm{~A} 4$ & A5 & A6 & A7 & A8 & A9 & A10 & A11 & A12 & A13 & A14 & A15 & A16 & \begin{tabular}{|l|} 
A17 \\
\end{tabular} & A18 & \begin{tabular}{|l|} 
A19 \\
\end{tabular} & A20 & A21 & A22 & \\
\hline E1 & 9 & 3 & & & & & & & & & & & & & & & & & & & & & 8.4 \\
\hline E2 & & & 3 & & & & & & & & & & & & & & & & & & & & 7.5 \\
\hline E3 & & & & 9 & 3 & 3 & 3 & & & & & & & & & & & & & & & & 8.1 \\
\hline $\mathrm{E} 4$ & & & & & & & & 3 & & & & & & & & & & & & & & & 6.3 \\
\hline E5 & & & & & & & & & 9 & & & & & & & & & & & & & & 6.2 \\
\hline E6 & & & & & & & & & & 3 & & & & & & & & & & & & & 7.4 \\
\hline E7 & & & & & & & & & & & 1 & 3 & & & & & & & & & & & 7.6 \\
\hline E8 & & & & & & & & & & & & & 1 & & & & & & & & & & 6.8 \\
\hline E9 & & & & & & & & & & & & & & 3 & & & & & & & & & 8.0 \\
\hline E10 & & & & & & & & & & & & & & & 3 & & & & & & & & 5.7 \\
\hline E11 & & & & & & & & & & & & & & & & 9 & & & & & & & 5.6 \\
\hline E12 & & & & & & & & & & & & & & & & & 3 & & & & & & 7.2 \\
\hline E13 & & & & & & & & & & & & & & & & & & 3 & & & & & 6.2 \\
\hline E14 & & & & & & & & & & & & & & & & & & & 3 & & & & 7.7 \\
\hline E15 & & & & & & & & & & & & & & & & & & & & 3 & & & 7.2 \\
\hline E16 & & & & & & & & & & & & & & & & & & & & & 9 & & 7.3 \\
\hline E17 & & & & & & & & & & & & & & & & & & & & & & 9 & 8.0 \\
\hline Occurance & 6.1 & 6.3 & \begin{tabular}{|l|}
6.4 \\
\end{tabular} & \begin{tabular}{|l|}
7.7 \\
\end{tabular} & 7.3 & 7.9 & \begin{tabular}{|l|}
8.4 \\
\end{tabular} & 6.1 & 5.6 & \begin{tabular}{|l|}
8.4 \\
\end{tabular} & 5.3 & 5.6 & 7.2 & 7.5 & 6.7 & 6.3 & 6.0 & \begin{tabular}{|l|}
7.1 \\
\end{tabular} & \begin{tabular}{|l|}
7.2 \\
\end{tabular} & 7.6 & 7.4 & 6.8 & \\
\hline ARP & 454.7 & 156.6 & 154.6 & 554.2 & 175.1 & 190.8 & 201.7 & 113.4 & 307.2 & 185.4 & 40 & 126.8 & 48.3 & 177.7 & 113.6 & 315 & 128.7 & \begin{tabular}{|l|}
131 \\
\end{tabular} & 165.2 & 161.9 & 479.6 & 483 & \\
\hline Rank & 4 & 14 & 15 & 1 & 11 & 8 & 7 & 20 & 6 & 9 & $22 \mid$ & 18 & 21 & 10 & 19 & 5 & 17 & 16 & 12 & 13 & 3 & 2 & \\
\hline
\end{tabular}

Dari Tabel 8 akan didapatkan prioritas penyebab risiko yang harus ditangani terlebih dahulu yaitu penyebab risiko (risk agent) dengan $\mathrm{A} 4$, penerbitan purchase order (PO) yang terlambat 
merupakan rangking pertama penyebab risiko gading utama (main frame). Tindakan yang lebih lanjut dibutuhkan untuk mengelola penyebab risiko (risk agent). Oleh karena itu, 22 penyebab risiko (risk agent) perlu diberikan penanganan pada fase House of Risk (HOR II).

\section{b. Gading Utama (Main Frame)}

Table 9 Matriks HOR I Gading Utama (Main Frame)

\begin{tabular}{|c|c|c|c|c|c|c|c|c|c|c|c|c|c|c|c|c|c|c|}
\hline \multirow{2}{*}{ Risk Event } & \multicolumn{17}{|c|}{ Risk Agent } & \multirow{2}{*}{ Severity } \\
\hline & $\mathrm{A} 1$ & $\mathrm{~A} 2$ & $\mathrm{~A} 3$ & $\mathrm{~A} 4$ & A5 & A6 & A7 & $\mathrm{A} 8$ & A9 & A10 & A11 & A12 & A13 & A14 & A15 & \begin{tabular}{|l|} 
A16 \\
\end{tabular} & A17 & \\
\hline E1 & 3 & & & & & & & & & & & & & & & & & 8.4 \\
\hline E2 & & 3 & & & & & & & & & & & & & & & & 8.2 \\
\hline E3 & & & 3 & & & & & & & & & & & & & & & 8.2 \\
\hline $\mathrm{E} 4$ & & & & 3 & & & & & & & & & & & & & & 6.6 \\
\hline E5 & & & & & 9 & & & & & & & & & & & & & 8.1 \\
\hline E6 & & & & & & 9 & & & & & & & & & & & & 6.2 \\
\hline E7 & & & & & & & 9 & 3 & & & & & & & & & & 7.7 \\
\hline E8 & & & & & & & & & 3 & & & & & & & & & 7.2 \\
\hline E9 & & & & & & & & & & 9 & 9 & & & & & & & 6.5 \\
\hline E10 & & & & & & & & & & & & 3 & & & & & & 5.7 \\
\hline E11 & & & & & & & & & & & & & 9 & & & & & 7.2 \\
\hline E12 & & & & & & & & & & & & & & 9 & & & & 7.1 \\
\hline E13 & & & & & & & & & & & & & & & 9 & & & 8.5 \\
\hline E14 & & & & & & & & & & & & & & & & 3 & & 8.3 \\
\hline E15 & & & & & & & & & & & & & & & & & 9 & 7.9 \\
\hline Occurance & 7.2 & 6.1 & 7.1 & 6.2 & 5.9 & 8 & 7.8 & 7.3 & 6.3 & 6.7 & 6.5 & 6.9 & 5.9 & 6.8 & 7 & 7.5 & 6.5 & \\
\hline ARP & 180.4 & 150.1 & 174.7 & 122.8 & 427.5 & 442.8 & 537.0 & 167.5 & 135.1 & 388.9 & 377.3 & 118.0 & 379.7 & 434.5 & 532.4 & 185.6 & 462.2 & \\
\hline Rank & 11 & 14 & 12 & 16 & 6 & 4 & 1 & 13 & 15 & 7 & 9 & 17 & 8 & 5 & 2 & 10 & 3 & \\
\hline
\end{tabular}

Dari Tabel 9 akan didapatkan prioritas penyebab risiko yang harus ditangani terlebih dahulu yaitu penyebab risiko (risk agent) dengan A15, ketidakakuratan penjabaran budget merupakan rangking pertama penyebab risiko gading utama (main frame). Tindakan yang lebih lanjut dibutuhkan untuk mengelola penyebab risiko (risk agent). Oleh karena itu, 17 penyebab risiko (risk agent) perlu diberikan penanganan pada fase House of Risk (HOR II).

\section{B. Evaluasi Risiko}

Dari hasil matriks HOR I pada Tabel 8 dan Tabel 9, maka diketahui nilai penyebab risiko (risk agent) yang paling tinggi. Pemilihan penyebab risiko yang diprioritaskan untuk ditindaklanjuti dilakukan dengan diagram pareto. Dalam penanganan risiko, tidak semua penyebab risiko (risk agent) mendapatkan penanganan. Hal ini disebabkan oleh bebrapa faktor yaitu biaya, waktu dan mutu hasil yang tidak sesuai serta penyebab risiko dianggap masih terlalu kecil dan masih dapat ditangani. Berikut hasil diagram pareto dapat dilihat pada gambar 4 dan 5 .

a. Pelat Geladak Utama Tepi $8 \mathrm{~mm}$ dan Pelat Geladak Utama Tipikal $12 \mathrm{~mm}$ 


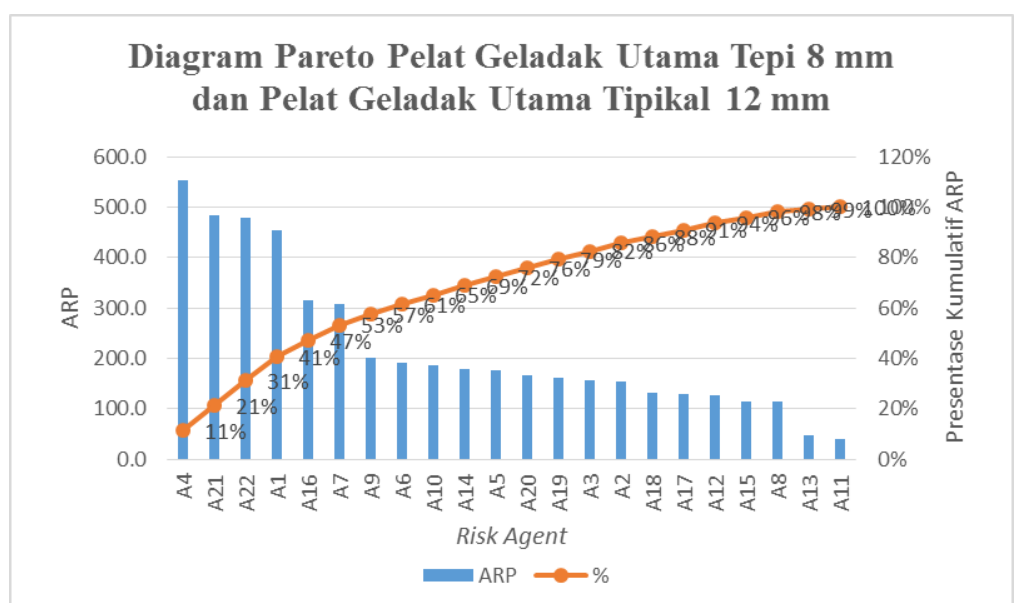

Figure 4 Diagram Pareto Pelat Geladak Utama Tepi $8 \mathrm{~mm}$ dan Pelat Geladak Utama Tipikal $12 \mathrm{~mm}$

Hasil diagram pareto pada gambar 3, maka penyebab risiko (risk agent) yang memberi pengaruh besar dan perlu diberikan penanganan berjumlah 14 risk agent yaitu, (A4) penerbitan Purchase Order (PO) terlambat, (A21) ketidakakuratan penjabaran budget, (A22) teknik dan metode estimasi yang kurang tepat, (A1) jenis material dan komponen tidak didefinisikan dengan jelas di dalam kontrak, (A16) SDM bekerja tidak efektif, (A7) lamanya negoisasi pembelian, (A9) alat angkut yang tersedia tidak memadai, (A6) spesifikasi komponen tidak bisa dipenuhi oleh satu supplier, (A10) kenaikan kurs mata uang yang tidak menentu, (A14) kelalaian dari pihak supplier, (A5) detail spesifikasi komponen tidak lengkap, (A20) buruknya track record galangan dalam proses pembayaran, (A19) Purchase Order (PO) yang diterbitkan tidak sesuai dengan anggaran, dan (A3) rendahnya kemampuan manajerial/ leadership.

b. Gading Utama (Main Frame)

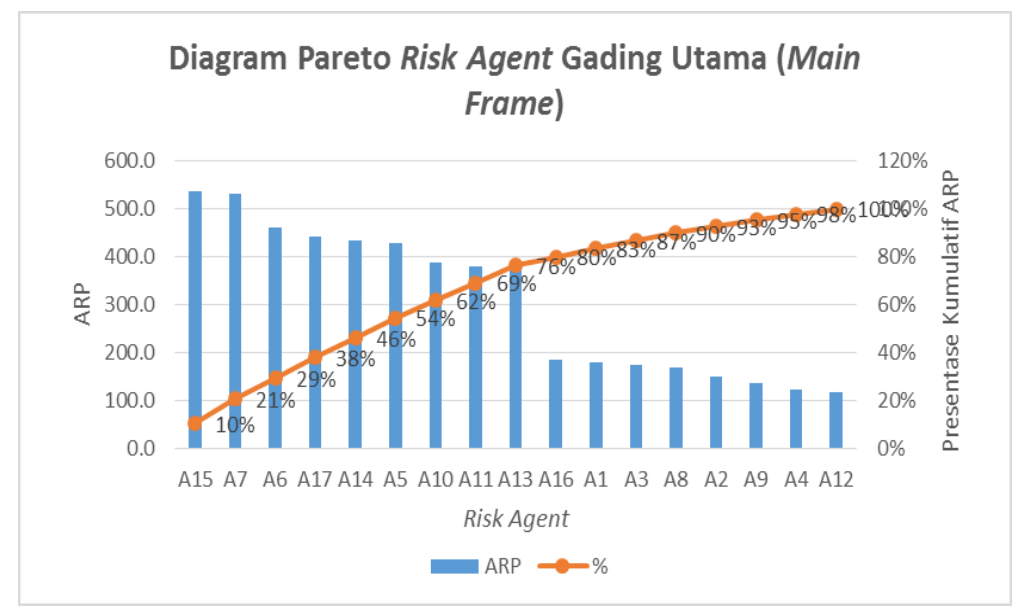

Figure 5 Diagram Pareto Gading Utama (Main Frame)

Hasil diagram pareto pada gambar 4, maka penyebab risiko (risk agent) yang memberi pengaruh besar dan perlu diberikan penanganan berjumlah 11 risk agent yaitu, (A15) ketidakakuratan penjabaran budget, (A7) perubahan desain dari pihak owner, (A6) proses persetujuan ijin yang bertele-tele, (A17) teknik dan metode estimasi yang tidak tepat, (A14) spesifikasi material dan komponen tidak jelas, (A5) ketidaktersediaan designer yang berpengalaman, (A10) evaluasi teknis yang berlarut-larut, (A11) terjadi perselisihan (perbedaan pendapat) antara aktor proyek, 
(A13) SDM tidak memenuhi kompetensi, (A16) data dan informasi proyek tidak lengkap, dan (A1) ketidaklengkapan drawing list.

\section{Tindakan Pencegahan (HOR II)}

Pada fase HOR II akan dibahas tindakan pencegahan terhadap penyebab risiko yang teridentifikasi pada fase HOR I. House of Risk II digunakan untuk menentukan tindakan pencegahan (preventive action) yang dilakukan dengan melihat keterlibatan sumber dan tingkat kesulitan dalam melakukan aksi tindakan pencegahan.

a. Pelat Geladak Utama Tepi $8 \mathrm{~mm}$ dan Pelat Geladak Utama Tipikal $12 \mathrm{~mm}$

Table 10 Matriks HOR II Pelat Geladak Utama Tepi $8 \mathrm{~mm}$ dan Pelat Geladak Utama Tipikal $12 \mathrm{~mm}$

\begin{tabular}{|c|c|c|c|c|c|c|c|c|c|c|c|c|c|c|c|c|c|c|c|c|c|}
\hline \multirow{2}{*}{$\begin{array}{c}\text { Risk } \\
\text { Agent }\end{array}$} & \multicolumn{20}{|c|}{ Preventive Action } & \multirow{2}{*}{ ARP } \\
\hline & PAl & PA2 & PA3 & PA4 & PA5 & PA6 & PA7 & PA8 & PA9 & PA10 & PA11 & \begin{tabular}{|l|l|} 
PA12 \\
\end{tabular} & PA13 & PA14 & PA15 & PA16 & \begin{tabular}{|l|} 
PA17 \\
\end{tabular} & \begin{tabular}{|l|} 
PA18 \\
\end{tabular} & PA19 & PA20 & \\
\hline A4 & 3 & 9 & & & & & & & & & & & & & & & & & & & 554.2 \\
\hline A21 & & & 9 & & & & & & & & & & & & & & & & & & 483.0 \\
\hline $\mathrm{A} 22$ & & & & 1 & & & & & & & & & & & & & & & & & 479.6 \\
\hline $\mathrm{Al}$ & & & & & 9 & 3 & & & & & & & & & & & & & & & 454.7 \\
\hline $\mathrm{A} 16$ & & & & & & & 9 & 9 & & & & & & & & & & & & & 315.0 \\
\hline A7 & & & & & & & & & 3 & 3 & 1 & & & & & & & & & & 307.2 \\
\hline A9 & & & & & & & & & & & & 3 & & & & & & & & & 201.7 \\
\hline $\mathrm{A} 6$ & & & & & & & & & & & & & 9 & & & & & & & & 190.8 \\
\hline $\mathrm{A} 10$ & & & & & & & & & & & & & & 9 & & & & & & & 185.4 \\
\hline $\mathrm{A} 14$ & & & & & & & & & & & & & & & 9 & 9 & & & & & 177.7 \\
\hline $\mathrm{A} 5$ & & & & & & & & & & & & & & & & & 3 & & & & 175.1 \\
\hline A20 & & & & & & & & & & & & & & & & & & 9 & & & 165.2 \\
\hline $\mathrm{A} 19$ & & & & & & & & & & & & & & & & & & & 3 & & 161.9 \\
\hline $\mathrm{A} 3$ & & & & & & & & & & & & & & & & & & & & 9 & 156.6 \\
\hline Tek & 1662.7 & 4988.2 & 4346.7 & 479.6 & 4091.9 & 1364.0 & 2835.0 & 2835.0 & 921.6 & 921.6 & 307.2 & 605.0 & 1717.1 & 1668.3 & 1599.1 & 1599.1 & 525.3 & 1487.2 & 485.8 & 1409.1 & \\
\hline $\mathrm{Dk}$ & 3.3 & 3.1 & 3.0 & 3.1 & 3.0 & 3.0 & 3.0 & 3.3 & 3.5 & 3.3 & \begin{tabular}{|l|}
3.4 \\
\end{tabular} & 3.5 & 3.0 & 3.0 & \begin{tabular}{|l|}
3.1 \\
\end{tabular} & 3.0 & 3.0 & 3.2 & 3.1 & 3.0 & \\
\hline EDK & 511.6 & 1609.1 & 1448.9 & 157.2 & 1364.0 & 454.7 & 945.0 & 859.1 & 263.3 & 283.6 & 90.4 & \begin{tabular}{|l|}
175.4 \\
\end{tabular} & 572.4 & 556.1 & \begin{tabular}{|l|}
515.9 \\
\end{tabular} & \begin{tabular}{|l|}
533.0 \\
\end{tabular} & \begin{tabular}{|c|}
175.1 \\
\end{tabular} & \begin{tabular}{|l|}
464.7 \\
\end{tabular} & 159.3 & 469.7 & \\
\hline Rank & 10 & 1 & 2 & 19 & 3 & 13 & 4 & 5 & 15 & 14 & 20 & 16 & 6 & 7 & 9 & 8 & 17 & 12 & 18 & 11 & \\
\hline
\end{tabular}

Pada Tabel 10, hasil perhitungan pada tahap House of Risk II didapatkan hasil peringkat tindakan pencegahan (preventive action) yang harus dilakukan terlebih dahulu. Dengan menggunakan diagram pareto maka tindakan pencegahan (preventive action) yang perlu dilakukan terlebih dahulu berjumlah 11 yaitu, (PA2) koordinasi antara divisi proyek dengan divisi purchasing untuk menentukan PO yang harus diprioritaskan, (PA3) memberikan data informasi material dan komponen yang nyata (real), (PA5) jenis material dan komponen mengikuti informasi digambar, (PA7) melakukan pelatihan (training), (PA8) memberikan reward, punishment, dan motivasi kerja pada seluruh tenaga kerja, (PA13) melakukan evaluasi kinerja supplier, (PA14) pengawasan terhadap perubahan harga, (PA16) memutuskan hubungan kerjasama dengan supplier, (PA15) mengurangi order kepada supplier, (PA1) membuat prosedur pengawasan Purchase Order (PO), (PA20) training peningkatan manajerial/leadership. 
b. Gading Utama (Main Frame)

Table 11 Matriks HOR II Gading Utama (Main Frame)

\begin{tabular}{|c|c|c|c|c|c|c|c|c|c|c|c|c|c|c|c|}
\hline \multirow{2}{*}{$\begin{array}{c}\text { Risk } \\
\text { Agent }\end{array}$} & \multicolumn{14}{|c|}{ Preventive Action } & \multirow{2}{*}{ ARP } \\
\hline & PA1 & PA2 & PA3 & PA4 & PA5 & PA6 & PA7 & PA8 & PA9 & PA10 & PA11 & PA12 & PA13 & PA14 & \\
\hline A15 & 3 & 9 & & & & & & & & & & & & & 537.0 \\
\hline A7 & & & 9 & & & & & & & & & & & & 532.4 \\
\hline $\mathrm{A} 6$ & & & & 1 & & & & & & & & & & & 462.2 \\
\hline $\mathrm{A} 17$ & & & & & 3 & & & & & & & & & & 442.8 \\
\hline $\mathrm{A} 14$ & & & & & & 9 & 9 & 9 & & & & & & & 434.5 \\
\hline A5 & & & & & & & & & 9 & & & & & & 427.5 \\
\hline $\mathrm{A} 10$ & & & & & & & & & & 3 & & & & & 388.9 \\
\hline A11 & & & & & & & & & & & 9 & & & & 379.7 \\
\hline $\mathrm{A} 13$ & & & & & & & & & & & & 9 & & & 377.3 \\
\hline $\mathrm{A} 16$ & & & & & & & & & & & & & 3 & & 185.6 \\
\hline $\mathrm{A} 1$ & & & & & & & & & & & & & & 9 & 180.4 \\
\hline TEk & 1611.1 & 4833.3 & 4791.2 & 462.2 & 1328.4 & 3910.7 & 3910.7 & 3881.7 & 3847.1 & 1166.8 & 3417.0 & 3395.9 & 556.9 & 1623.2 & \\
\hline Dk & 4.0 & 3.2 & 4.0 & 3.5 & 3.0 & 4.0 & 3.5 & 3.1 & 3.0 & 3.2 & 3.0 & 3.0 & 3.0 & 3.1 & \\
\hline ETDk & 402.8 & 1510.4 & 1197.8 & 132.0 & 442.8 & 977.7 & 1117.3 & 1252.2 & 1282.4 & 364.6 & 1139.0 & 1132.0 & 185.6 & 532.2 & \\
\hline Rank & 11 & 1 & 4 & 14 & 10 & 8 & 7 & 3 & 2 & 12 & 5 & 6 & 13 & 9 & \\
\hline
\end{tabular}

Pada Tabel 11, hasil perhitungan pada tahap House of Risk II didapatkan hasil peringkat tindakan pencegahan (preventive action) yang harus dilakukan terlebih dahulu. Dengan menggunakan diagram pareto maka tindakan pencegahan (preventive action) yang perlu dilakukan terlebih dahulu berjumlah 8 yaitu, (PA2) yaitu mengerjakan laporan termin sesuai dengan target yang telah ditentukan, (PA9) yaitu merekrut tenaga kerja/designer yang kompeten (memiliki keahlian dan pengalaman), PA8 yaitu mengambil pengalaman pembuatan kapal sebelumnya yang pernah dikerjakan, (PA3) yaitu membuat perjanjian bersama antara kontraktor dan owner, (PA11) yaitu meningkatkan komunikasi dan koordinasi antara aktor proyek, (PA12) yaitu pelatihan/training peningkatan manajerial dan kemampuan masing-masing kompetensi, (PA7) yaitu mencari informasi pada gambar kerja, dan (PA6) yaitu memperbaiki sistem kinerja proses pengadaan material dan komponen.

\section{Kesimpulan dan Saran}

\subsection{Kesimpulan}

Berdasarkan analisis data dan pembahasan, maka dapat disimpulkan bahwa:

a. Material dan komponen berupa bahan baku pembuatan kapal Ro-Ro 300 GT Danau Toba yang mempunyai risiko ekstrim adalah pelat geladak utama tepi $8 \mathrm{~mm}$, pelat geladak utama tipikal $12 \mathrm{~mm}$ dan gading utama (main frame).

b. Hasil identifikasi risiko keterlambatan material dan komponen YAng dilakukan dengan pengukuran occurance dan severity diperoleh risiko pelat geladak utama tepi $8 \mathrm{~mm}$ dan pelat geladak utama tipikal $12 \mathrm{~mm}$ sebanyak 17 kejadian risiko (risk event) dan 22 penyebab risiko (risk agent), dan gading utama (main frame) sebanyak 15 kejadian risiko (risk event) dan 17 penyebab risiko (risk agent).

c. Hasil HOR I, pelat geladak utama tepi $8 \mathrm{~mm}$ dan pelat geladak utama tipikal $12 \mathrm{~mm}$ didapatkan dari 22 penyebab risiko terdapat 14 penyebab risiko yang memberi pengaruh besar, sedangkan gading utama (main frame) didapatkan dari 17 penyebab risiko terdapat 11 penyebab risiko yang perlu diberikan penanganan. Hasil HOR II, menunjukkan pelat geladak utama tepi $8 \mathrm{~mm}$ 
dan pelat geladak utama tipikal $12 \mathrm{~mm}$ dari 20 tindakan pencegahan terdapat 11 tindakan pencegahan dan gading utama (main frame) dari 14 tindakan pencegahan terdapat 8 tindakan pencegahan yang perlu dilakukan terlebih dahulu.

\subsection{Saran}

Dalam pengaplikasian strategi tindakan pencegahan untuk penelitian selanjutnya, perlu dilakukan pengukuran besar dampak risiko yang berkurang apabila usulan aksi berupa tindakan pencegahan dilakukan pada proyek, dan dapat menambah variabel dalam peninjauan kejadian risiko, penyebab risiko dan tindakan pencegahan untuk mengetahui dengan jelas pekerjaaan di dalam proyek.

\section{Acknowledgement}

Penulis mengucapkan terimakasih kepada pihak-pihak yang membantu dalam proses penyusunan dan penyelesaian Tugas Akhir ini, yaitu: Bapak Hadi Sutanto Saragi, S.T, M. Eng selaku Dosen Pembimbing Utama yang senantiasa meluangkan waktunya untuk memberikan bimbingan, ilmu, saran, semangat serta nasehatnya. Bapak Dimas Munandar selaku Project Manager (PM) dan semua pihak terkait pada proyek pembangunan kapal Ro-Ro 300 GT Danau Toba, yang bersedia membantu dan memberikan informasi yang dibutuhkan dalam pengerjaan Tugas Akhir. Serta pihak terkait lainnya yang tidak dapat penulis sebutkan satu per satu yang telah memberikan bantuan dan dukungan dalam penyusunan dan penyelesaian Tugas Akhir.

\section{REFERENSI}

[1] Hanafi Mamduh M. (2009) "Manajemen risiko ( $2^{\text {nd }}$ ed)."

[2] Project Management Institute. (2008) "A guide to the project management body of knowledge (PMBOK ${ }^{@}$ Guide)."

[3] Darmawi Herman. (2005) "Manajemen Risiko"

[4] Zulia Dewi Cahyani, Sri Rejeki Wahyu Pribadi, and Imam Baihaqi. (2016) "Studi implementasi model house of risk untuk mitigasi risiko keterlambatan material dan komponen impor pada pembangunan kapal baru." Jurnal Teknik 5 (2): 1-8.

[5] Iman Soeharto. (1995) "Manajemen proyek dari konseptual sampai operasional."

[6] Turner J. Rodney. (1992) "The handbook of project based management: improving process for achieving your strategic objectives."

[7] I. Nyoman Pujawan, Laudine H. Geraldin. (2009) "House of risk: a model for achievieng your strategic objectives." Jurnal Business Process Management, 15 (6): 963-967.

[8] Standard Australia Licence. (1999) “AS/NZS 4360: 1990 Risk Management."

[9] Taufiq Immawan, Dea Kusuma Putri. (2018) "House of risk approach for assessing supply chain risk management strategies: a case study in Crumb Rubber Company Ltd." MATEC Web of Conferences.

[10]I. Nyoman Pujawan. (2005) "Supply chain management." 